\title{
シスブラチンとペプロマイシンの併用療法における 相乗効果発現の機序に関する研究
}

\author{
慶応義熟大学医学部耳舅咽啹科学教室（主任：斎藤成司教授） \\ 藤正人 \\ FUNDAMENTAL STUDY ON THE COMBINATION THERAPY \\ OF CISPLATIN AND PEPLOMYCIN
}

MASATO FUJII, M. D.

Department of Otolaryngology, School of Medicine, Keio University, Tokyo

Cisplatin (CDDP) and peplomycin (PEP) are effective new agents for chemotherapy of head and neck cancer. And the combination therapy of the two drugs is considered to have good synergistic effects. Despite the observances made in both basic experiments as well as in clinical trials, the mechanism of synergism, however, remains unknown. Experimental studies, therefore, were made to solve the mechanism of synergism.

First, combination therapy with CDDP and PEP was performed, using Ehrlich ascites carcinoma, in actual clinical dose schedule. CDDP was administered intra-peritoneally at day 0 , and PEP 48 hours later (day 3). This combination therapy with CDDP and PEP proved to have good synergistic effects.

As for the mechanism of synergism, one of the hypotheses was as follows. It was thought that nonprotein-bound CDDP with anti-cancer activity might be released from protein-bound CDDP when PEP is administered in combination. But after the experiment in vitio, using dog plasma, my conclusion is that CDDP is bound to plasma protein irreversively - thus denying this hypothesis.

The next study for the mechanism was to see the effects against cell cycle progression by flowcytometry process. It was found that at an early stage after single administration of CDDP, cell cycle progression was delayed in $S$ phase and blocked in G2 phase thereafter. Forty-eight hours after administration of CDDP, cells accumulated in G2-M phase. This change, however, proved to be reversible because cells returned to normal progression pattern 96 hours after single administration of CDDP. As for PEP in single administration, cell cycle progression was blocked in $\mathrm{G} 2-\mathrm{M}$ phase at an early stage; it was also reversible. In the case of combination therapy, cell cycle progression pattern proved irreversible, and damaged cells (debris) appeared at low channels. It is, therefore, assumed that cells are seriously and irreversibly damaged in combination therapy.

As result of the foregoing studies, one of the mechanism of synergism is thought to be as follows:

After administration of CDDP, cells are accumulated in $\mathrm{G} 2-\mathrm{M}$ phase. PEP is administered 48 hours after CDDP treatment when cells are most accumulated in $\mathrm{G} 2-\mathrm{M}$ phase. This brings 
about PEP's most efficient cytocydal effects since PEP has high sensitivity against cells in G2-M phase. This may explain one of the mechanism of synergism. And the high clinical respose rate in combination therapy of CDDP and PEP - when the former is administered first and the latter 48 hours after CDDP treatment - may be due to this mechanism.

Key words: Cisplatin, Peplomycin, Mechanism of Synergism

A88-0512-00355

\section{I はじめに}

貴頸部癌の臨床治療上，これまでの手術療法や放射 楾察法江加总化学療法の占める割合が近年增大しつつ ある. 頭頸部癌化学療法で虫, 従来より bleomycin や methotrexate が第一選択とされてきた。 近年わが国に 招いて, bleomycin の誘導体である peplomycin（以下 PEP）方開発され，bleomycin と同等あるいはそれ以上 との評価がなされている，当教室でも頭頸部扁平上皮癌 にたいして 58\%の奏效率を得ている1. 一方近年臨床研 究が進的ら机大白金化合物 cis-diamminedichloro platinum(II) (以下 CDDP) は新しいタイプの抗癌郕とし て注目されている。頭頸部癌侄対する有効性について は，1977年のWittes の報告 ${ }^{2}$ 以来数多くの報告がみら れる. 当教室飞执いても1978年より臨床治駼を開始し 頭頸部扁平上皮癌にたいし $38 \%$ の奏扸率を得た ${ }^{33}$.

著者らは，この CDDP と PEP を用いた併用療法に 注目し，臨床研究とともに基礎研究を行ってきた。基礎 研究として法, 当教室の增野らが Ehlrich 腹水癌やヌー トマウスを用いた併用実験を行い，上り優れた相乗効果 の得られる投与法，投与スケジュールを㛟討した出5．

その結果, CDDP 先行投与する新しい regimen 開 発し，1981年より跕床に導入し，78\%という原れた奏效 率を得た ${ }^{6}$. この奏効率は両薬剤単独の奏効率を大きく

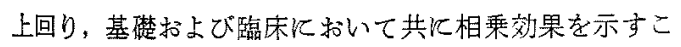
とが確認された。

しかしながら，この2剤の併用療法が相乘効果を示す 機序についてはまだ不明であり，今回その点関して基

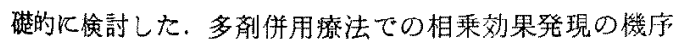

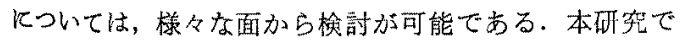
はまず踟床化近い投与スケジュールで Ehlrich 腹水癌に 対し CDDP と PEP 療法併用を施行し相乗勃果を検討 した（実験 1). 次沃 CDDP と PEP の薬物動態飞注目 して検討を行った，すなわち CDDP と血漿蛋白との結 合仗对する PEP の影響を検討した（実験 2). 次いで 併用癔法に招ける細胞動態に注目した。すなわち実驗 1
と同一の条件括よび投与スケジュールで CDDPと PEP の併用療法を施行し，細胞周期内進行儿改ほ古作用上薬 剂感受性の細胞周期依存性の観点加検討を加えた（実 跧 3).

その結果, CDDP 上PEP の作用機序に関して若干の 知見を得たので，報告する。

$$
\text { II 材料 }
$$

1. 蒋郕

CDDP (Lot No. 0120) および PEP (Lot No. u0101s)

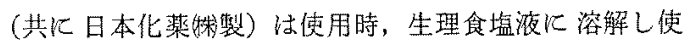
用した。

\section{2. 犬血整}

堆性ビーグル犬（日本化蒋悈安全性研究所）上り血液 を採取し，へパリンを加充て $3000 \times \mathrm{g}$ ，10分閶遠心分溻 して血漿を得た。

3.マウス

ICR 系6 週㱓雄性マウスを使用し1群に対し8匹と した.

\section{III 実 験 方 法}

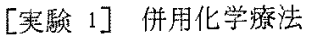

マウスの腹垫内に Ehlrich 腹水癌細胞 $5 \times 10^{6}$ 個を day 0 に移植した. day $1 k \operatorname{CDDP} 2,4,8 \mathrm{mg} / \mathrm{kg}$, 次いで day 3 K PEP 8, 16, $32 \mathrm{mg} / \mathrm{kg}$ を腹腔内投与 した．同スケジュール，同投与量で CDDP および PEP の单独投与群屯設けた。対照群には同様に生理食塩液を 投与した，艺の後 day 60 までマウスの生死を観察し， 各群についての平均生存日数を求的た。併用群のILS (increase in life span) が各菂剤の単独投与群の ILS の和を越えた時相乗勏果があると判定した。

[実験 2] 犬血隼中での蛋白非結合型 CDDP 濃度の 経時的変化

犬血繁 $50 \mathrm{~m} l k \mathrm{CDDP}$ を $5 \mu \mathrm{g} / \mathrm{m} l$ となるように加

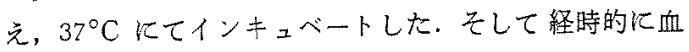




\section{Sampling Schedule of Tumor Cells after Treatment with CDDP. and PEP}
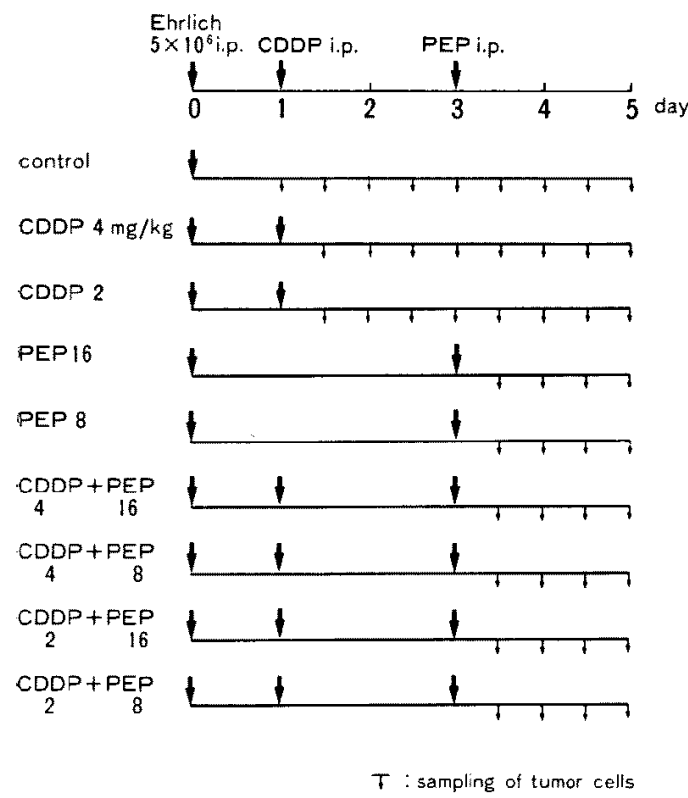

図 1 CDDP，PEP の投与スケジュール，捻 よび Ehlrich 腹水癌細胞㨲取のスケシ ュール

禁を採取し，蛋白非結合型 CDDP の濃度を㵋定した。 また，CDDPを同様の条件で添加し，さらに PEPを $4 \mu \mathrm{g} / \mathrm{ml}$ となるように添加した場合についても同様に 㮝討した。

次化 CDDP 持続的飞添加（最終濃度 $5 \mu \mathrm{g} / \mathrm{ml}$ ) 乙 た場合について, CDDP 単独括よび PEP 併用での蛋 白非結合型 CDDP 漕度の経時的な变化を検討した。

な扰蛋白非結合型 CDDP の分陫招よび定量法次の上 うな方法で行った，探取した試料は，ただちに Amicon Micro Partition System MPS-1 (1000×g 5 分) で限 外滤過を行い，その㴓液を蛋白非結合型 CDDP とした。 各試料中の白金瀑度は，フレームレス日立原子吸光光度 計 170-50A型を用いて測定した。検量線は CDDPを 生理食塩波飞溶解したものを用いて作成し測定值はすべ て CDDP 量に換算して表示した.

[実験 3] CDDP 执上び PEP 投与後に括ける細胞周 期内進行の経時的密化

CDDP，PEP 括よび両者の併用療法が細胞周期内進

\section{Method of Flowcytometry Analysis}

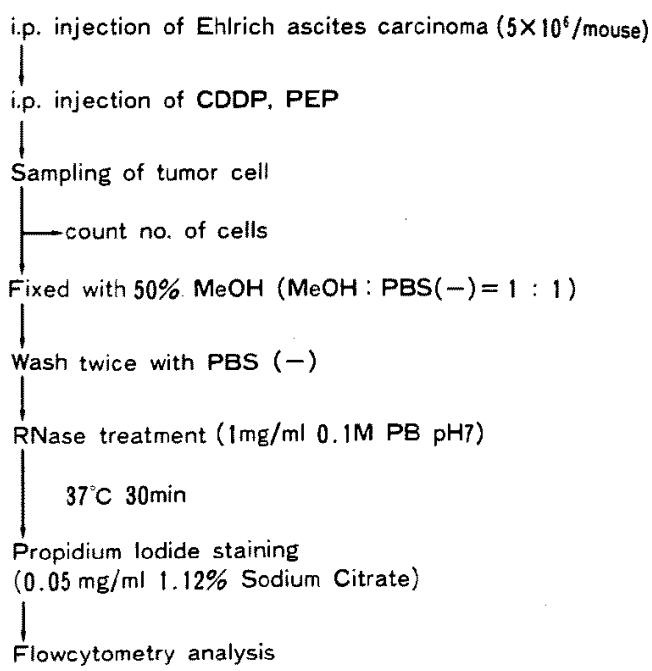

图 2 Flowcytometry によるDNA分布パタ ーン解析までの資料作成法

行に及ぼす影響を見るため，図2汇示す方法て DNAを 染色し flowcytometry による細胞内 DNA パターンの 解析を行った。るす，実験 1 と同一条件で Ehlrich腹水

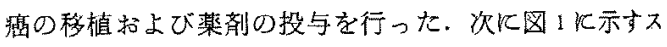
ケジュールで腹腔より Ehlrich 腹水癌細胞を採取し，ま ずコールターカウンター（ZB I 型）を用いて細䍖数を測 定した. さらにー20\% 一夜固定し，次いで 0.2 M リン酸䌅衙液 (pH 7.2) K て2回遠心洗净した。これKRNase ( $1 \mathrm{mg} / \mathrm{ml} 0.2$ Mリン酸纊衝液, $\mathrm{pH} 7.2)$ を $10^{6}$ 細胞あたり $0.2 \mathrm{ml}$ 加

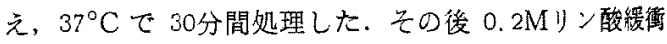
液（pH 7.2）で洗浄後，冷却した propidium iodide客 液 $(50 \mu / \mathrm{ml} 1.12 \%$ クエン酸ナトリウム溶液） $10 \mathrm{ml}$ 加光，冷蔵庫中で 2 時閔 DNAを染色した。そして cytofiuorograph A-4800 (Biophysics 社) 布を測定した。

\section{$N$ 結 果}

[実驗 1] 併用化学療法

CDDP 叔よび PEP 併用群の ILS は，CDDP $8 \mathrm{mg} /$ $\mathrm{kg}$ 执よび PEP $8 \mathrm{mg} / \mathrm{kg}$ 投与の場合を除き，各々の単 独投与の場合のILS の和と比較していずれ季高値を示 して扣り，相乘効果が諗められた（因 3).

[実魜 2] 犬血浆中での蛋白非結合型 CDDP 湿度の 
Combination Chemotherapy of CDDP with PEP Against Ehrlich Ascites Carcinoma in Mice

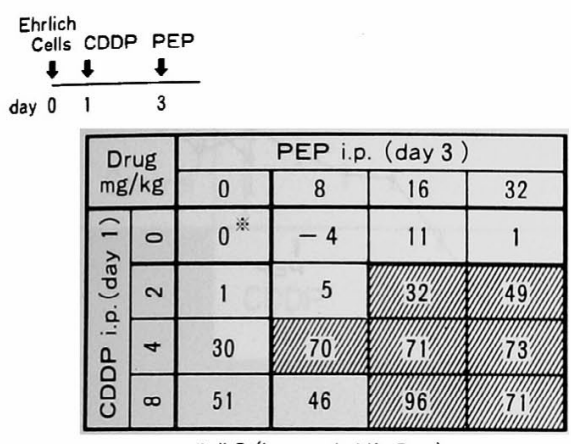

裳 ILS (Increase in Life Span)

目 3 CDDP と PEP の併用化学療法

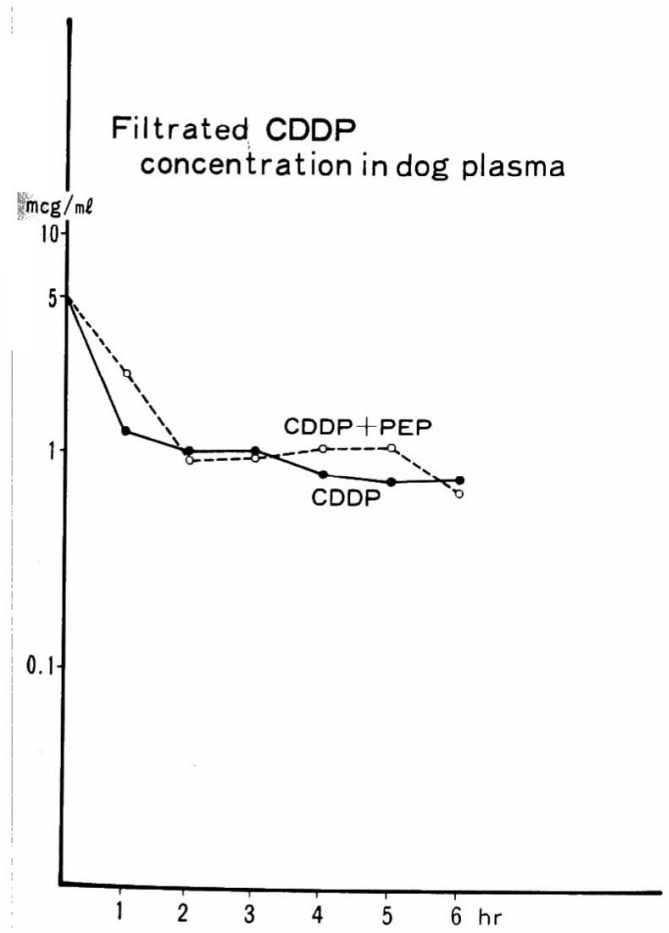

図 4 犬血漿中下 CDDP, PEP 添加後の蛋白 非結合型 CDDP の濃度变化

\section{経時的变化}

图4亿示すよう亿血漿中の蛋白非結合型 CDDP 濃度 は,インキュベーション開始後約 2 時間まで速やかて， またその後は緩やか減少した。この蛋白非結合型

\section{Filtrated CDDP concentration in dog plasma}

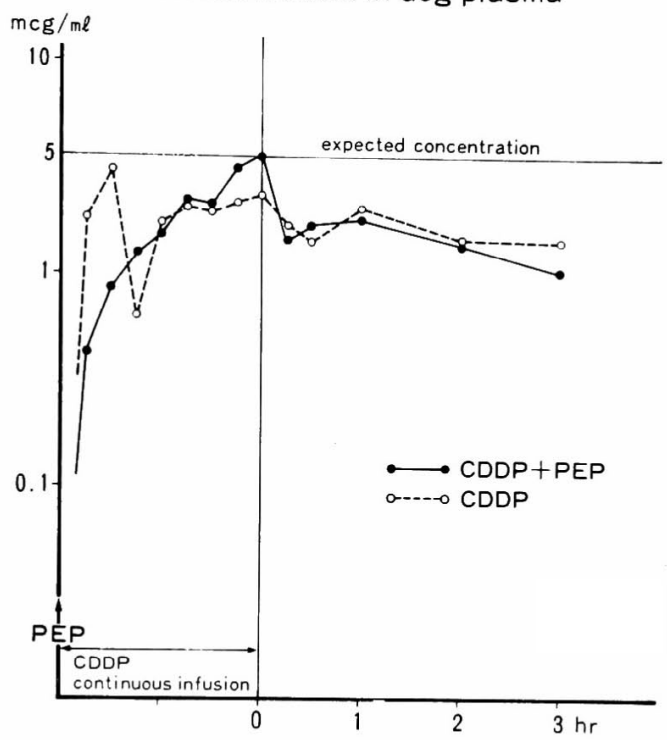

図 5 犬血漿中飞 PEP を添加し, CDDP を 2 時間飞わたり持続的飞添加した場合の 蛋白非結合型 CDDP の濃度变化

CDDP の濃度の減少住して，PEP は影響を及ほさな かった. また図 5 亿示すように CDDPを持続的に添加 （最終濃度 $5 \mu \mathrm{g} / \mathrm{m} l$ ) した場合飞抢いても蛋白非結合型 CDDP 濃度は PEP の存在により影響を受けなかった。

[実験 3］CDDP お上び PEP 投与後における細胞周 期内進行の経時的变化

まず細胞数の变化を, 図 $6,7,8$ 亿示す. CDDP 単 独投与の場合対照群に比べて, 細胞数は一時的に減少す るが, その後再び增加しており, その增加の割合は対照 群と同様であった。 また CDDP の投与量による顕著な 差は認好られなかった（図 6). PEP単独投与の場合屯, 投与後細胞数の減少を認めるものの, ほぼ対照群と同様 に增加した (図 7).

一方, CDDP と PEP の併用群では著明な細胞数の減 少が認められた。この減少の程度は CDDP と PEP の 投与量が高い組み合わせはど強く認められた（図 8).

次に Flowcytometryにより, 細胞内 DNA 分布パ ターンの 経時的な変化について解析した. CDDP を投 与すると 12 時間後に S 期の細胞数の增加が見られ, そ の後は G2-M 期に細胞の培積が起こり始めた. 投与 48 時間後には G2-M 期への細胞蓄積が著明となった。 
Cell Number after i.p. Injection of CDDP

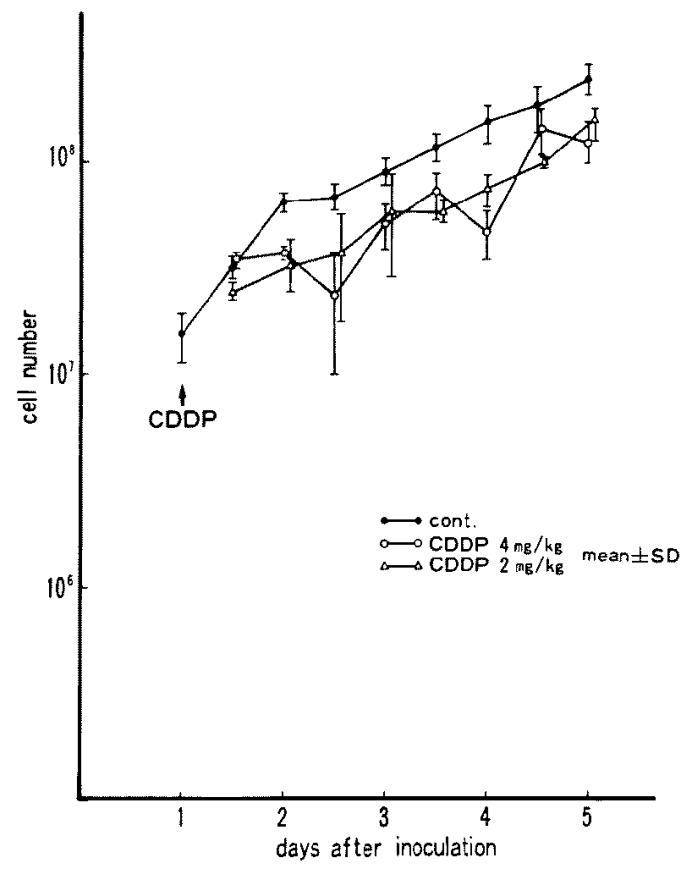

図 $6 \mathrm{CDDP}$ 投与後の Ehlrich 腹水癌細胞数の 变化

PEP 单独投与の愓合は，投与の12時間後で G2-M 期の 細胞蓄積が著明となった. CDDP 捛よび PEP の単独投 与の場合, G2-M 期以蓄積した細胞は時間の経過と共飞 再び周期内進行在開始し, CDDP では投与後 96時間, またPEPでは投与後 48時間仙は，ほほ投与前の DNA 分布パターンにもどっていた。これに対し CDDPと PEP の併用群では，併用後 G2-M 期への細胞蓄積が著 明であるが，その後の回復は㒻られず時間経過と共に G2-M 期の細胞は減少し，G1 期炕相当する DNA 量上 りも更に低チャンネルに破媢細炮（debris）によると思 われるバターンの出現をみた（図9).

$$
\mathrm{V} \text { 考察 }
$$

1. CDDP と PEP の Ehlrich 腹水癌任対する併用 効果

CDDP と PEP の併用療法化扮いて, 当教室では CDDP 投与の後，督障害の軽減を目的として hydration を施行するため，PEP の投与は1日あけて行っている. 実鲼 Iではこのような臨床の併用 regimen にあわ女
Cell Number after i.p. Injection of PEP

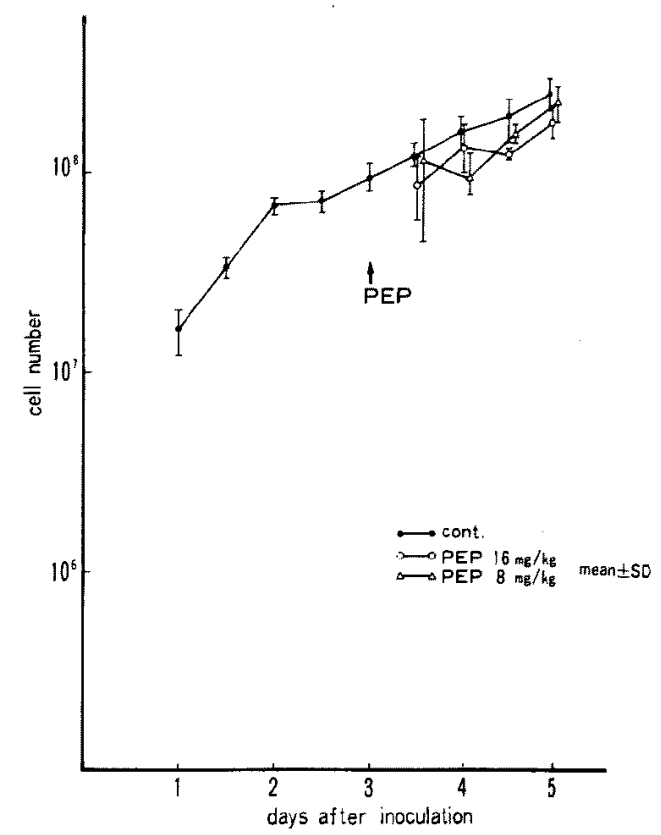

図 7 PEP 投与後の Ehlrich 腹水癌細粅数の 変化

て, CDDP と PEP の併用効果を Ehlrich 腹水售を用 いて挨討し，相乗効果を認めた。

增野らは，CDDP とPEP の投与順序について基碤的 飞研究し ${ }^{45)}$ ，同時併用招よび PEP の 1 日前先行投与と 比較して, $\operatorname{CDDP} の 1$ 日前先行投与の方方相乗斺果加 高く，また毒性も低いと報告している，本実弱の臨床て

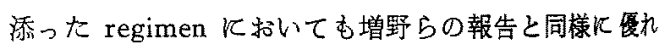
た相乘効果が認められた。

そこで前述の CDDP の先行投与による PEP との米

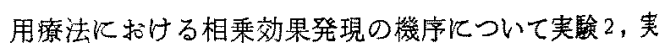
䖋 3 で检討した。

2. CDDP と血漿蛋白との結合炕対するPEP の影篦 CDDP の生体内動態については多くの報告が斿され ている.すなわち CDDP の投与後, 蛋白非結合型 CDDP は速やか消失するが，蛋白結合型 CDDP は長 く血中に留まることが報告されている，Holdener $b^{(0)}$ ，

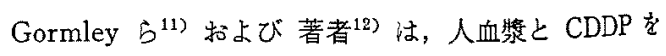
混和させると CDDP の殺細胞性が減少する事を見い甘 して数り，このことから蛋白結合型 CDDP の活性将非 常儿低く，蛋白非結合型 CDDP が抗腄場活性を持つと 
藤 井論 文付図

DNA distribution pattern of Ehlrich ascites carcinoma cells after i.p. injection of CDDP and PEP.

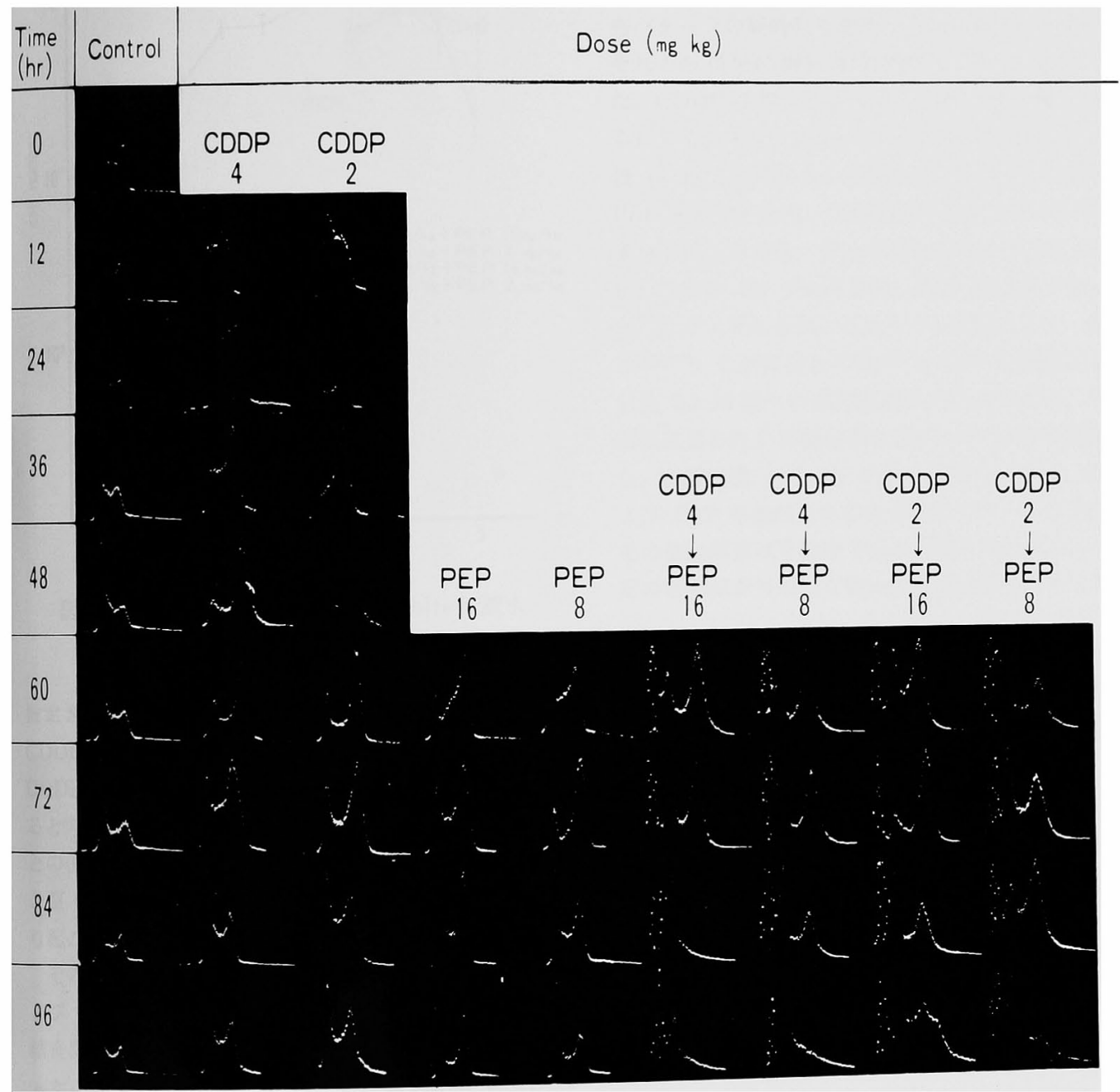

図 $9 \mathrm{CDDP}$ 及び PEP 投与後の D N A 分布パターンの経時的変化。 
Cell Number after i.p. Injection of CDDP and PEP

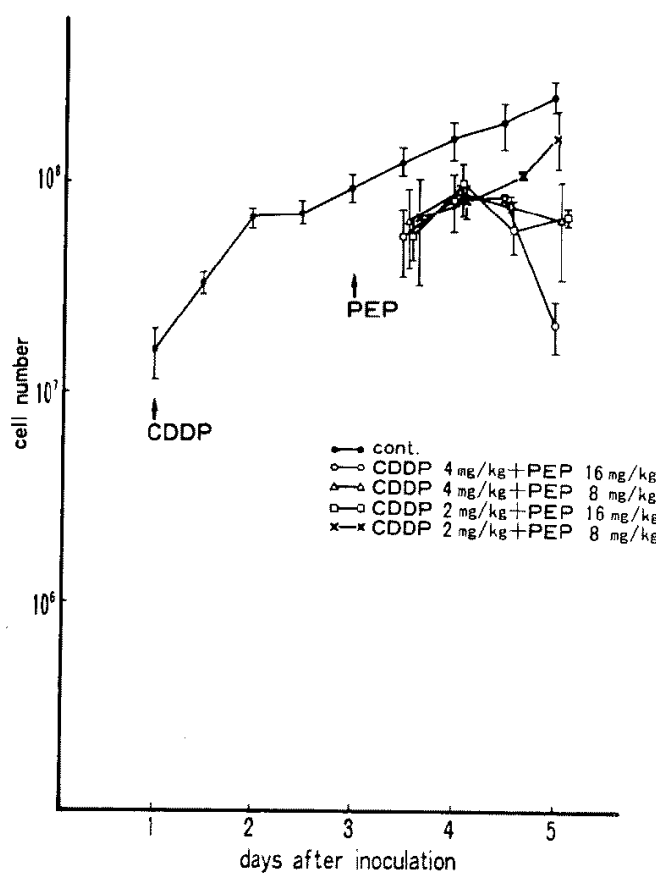

図 $8 \mathrm{CDDP}$ と PEP 併用後の Ehlrich 腹水 癌細胞数の变化

推定される.この投与後長く血中汇留まる蛋白結合型 CDDP 加ら, 何らかの機構に上り再び蛋白非結合型

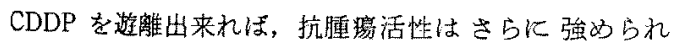

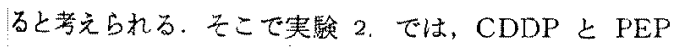
との併用勃果登現の機序の一つとしてこの上うな蛋白結 合型 CDDP からの CDDP の遊離が PEP の存在化よ り起こるか否かを検討した。

その結舆 CDDP と PEP を同時に添加した場合，お よび CDDP を持続的に添加した場合に扒いて，蛋白非 結合型 CDDP 濃度の变化は PEP により影響されなか った.すなわち PEP の併用炕より蛋白結合型 CDDP 加占活性のある CDDP が遊離されるとい万可能性玩否 定されると考元られる、Vermoken ${ }^{13)}$, Cole ${ }^{14)}$, Gonias $b^{15)}$ は CDDP と血繁蛋白の結合怯非可逆的でる上 しているが、このことは本結論を支持するむので市る ๖.

3. Ehlrich 腹水茩の細胞周期内進行飞対する作用 前述のよう飞薬物動態からは CDDPとPEP との併 用の機序を説明し得なかったため，次化併用療法に括け
る細胞動的，特に細胞周期内進行に及ほす作用の観点办 ら併用の機序を検討した. 実駼 3 K怙ける細胞数の变化 と、夷験1でのILS を指標とした併用効果の判定結果 を考え合わせると，併用篜法では強い細胞障害の結果相 乗效果が現れていることが推察される。

次に Flowcytometry に上り解析した細胞内 DNA 分 布パターンの経時的な变化から CDDP と PEP およひ それらの併用が細胞周期内進行飞及ほす影隌を检討し た、CDDPを投与するとまず S 期の細胞数の增加が見 られ，その後 G2-M 期飞細胞の蓄樍が起こり始的る。 投与48時間後飞は $\mathrm{G} 2-\mathrm{M}$ 期への細胞著積が著明上なる。 PEP 単独の場合は，投与の 12 時間後で $\mathrm{G} 2-\mathrm{M}$ 期の細胞

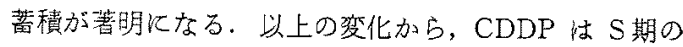
延長扔よび G2 ブロックを，PEP は G2 ブロックをひ き起こすと考学られ，これまでの報告とよく一致してい $ろ^{(6)-20)}$ 。これに対し CDDPとPEP の併用群では, 併 用後 G2-M 期への 細胞蓄積が算明であるが，その後の 回復は見られず時間経過と共飞 $\mathrm{G} 2-\mathrm{M}$ 期の細胞は隇少 し，破振細胞（debris）加多く出現している。CDDP 拉 よび PEP 単独投与の場合 DNA パターンの变化から, その細胞障害仙可逆的であると孝克られるのに対し，併 用の場合は非可逆的な強い細胞障害が起こると考えられ た.

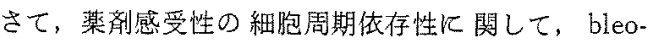
mycin は G2 期怙よび M 期の細胞飞対して相対的飞強 い殺細胞作用を示すことが報告されている21222)，bleomycin の誘導体である PEP K対しても同様の細胞周期 传存性を示すと考えられる。この事之 CDDP の細胞用

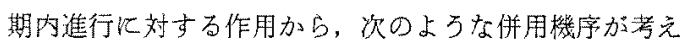
られる。すなわち，CDDP 投与で G2-M 期に細胞蓄積 が見られたことより細胞は G2 期涪部分同調化すると考 克られる。そこ人，夲の期化高い殺細胞作用を示す PEP 声投与することに上り效率的度細胞致死効果が発現され るものと考允られる。このような併用機序は, 寺島ら が報告した，G2ブロックを同き起こす X線 type の蒋

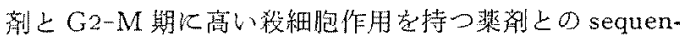
tial combination の例用機序に相当するものであり，強 い相乗勃果が得られるとされている。

従って，CDDP 投与に上り $\mathrm{G} 2-\mathrm{M}$ 期への細胞蓄積が 最も著明となる CDDP 投与48時間後飞 PEP を投与す る本併用スケジュールは併用機序の観点で最適なものと 考光られる. CDDP 先行投与により認められた優れた 臨床効果の発現に打いても，本機序が䦎与しているもの 
と考えられる。

\section{ま と め}

1. CDDPを先行投与しその48時間後に PEP を投与 する臨床投与スケジュール飞基づき, Ehlrich 腹水癌を 使用して CDDP と PEP の併用蜪法学施行し明らかな 相乘效果学得た。

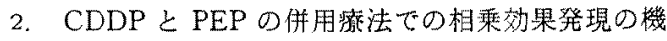
序として，PEP の併用に上り掻白結合型 CDDP 加ら活 性を有する蛋白非結合型 CDDP が遊徼されるか否加， の観点から in vitroに扮いて検討した. その結果 CDDP と血等蛋白との結合岋非可逆的で，この様应併用の機序 は認められなかった。

3. 細胞周期内進行に対与る作用加ら併用機序を模討 した.

CDDP の投与で細胞はまず $\mathrm{S}$ 期飞䔔積された。 その 後 48時間経過するとG2-M 期汇蓄積されてくるが，こ

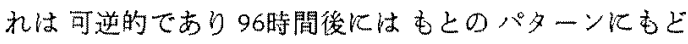
った、PEP の単独投与では投与後 G2-M 期への細胞蓄 積が見られたが，同様に可逆的であり投与48時間後には もとのパターンにもどっていた. これに対し CDDP と PEP の併用では DNA パターンは非可逆的な反応を示 し，破損細胞（debris）の出現や細胞数の減少などから 强い細胞障害が引き起こされると考えられた。

CDDP により G2-M 期への細胞蒛積が投与後 48時 間で最も著明となり，そこへ G2-M期の細胞に対して 高い殺細胞作用を示すPEP が投与されることにより効 果的な細胞致死効果が発現されることが，併用機序の一 つとして考えられた. CDDP の先行投与による優れた 跕㦿效果の発現において屯，本機序が関与しているもの と考光られる。

\section{参考文献}

1) 犬山征夫 他：碩頙部悪性尰瘵に対するNK-631 (Peplomycin) の効果飞ついて 耳骨臨床 71 : 1517-1527; 1978 .

2) Wittes et al: cis-diamminedichloroplatinum (II) (DDP) in the treatment of epidermoid carcinoma of the head and neck. Cancer Treat Rep 61: $359-366,1977$.

3) 犬山征夫他：頭䫫部癌飞対与る NK-801 (Cisplatin) の効舆について 耳鼻臨床 74:2701-2711, 1981.
4）增野精二他：Ehlrich 腹水癌に対する Cisplatin 々 Peplomycin の併用奻果について 日癌治 16: $314,1981$.

5）增野精二他： ヌードウス可移植性ヒト扁平上皮 癌に刘する CPDD と Peplomycinの併用效果に

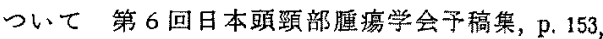
1982.

6) 犬山征夫 他：頭頸部癌に対するCisplatinとPeplo-

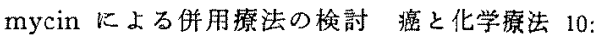
97-193, 1983.

7) Litterst CL et al: Distribution and disposition of platinum following intravenous administration of cis-diamminedichloroplatinum (II) (NSC 119875) to dogs. Cancer Res 36: 2340-2344, 1976.

8）堀内正䲄 他: Cis-dichlorodiammineplatinum(I) の体内動熊 癌と化学療法 9：632-637, 1982.

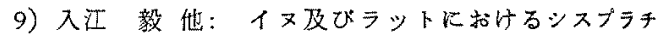
ンの吸收・排泄・分布医薬品研究 14:384-410, 1983.

10) Holdener EE et al: Effect of mannitol and plasma on the cytotoxicity of cisplatin. Cancer clin Oncol 19: 515-518, 1983.

11) Gormley $\mathrm{PE}$ et al: Kinetics of cis-dichlorodiammineplatinum. Cline Pharmacol Thr 25: $351-357,1979$.

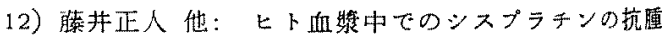
瘦活性について 癌と化学療法 11：1875-1876, 1984.

13) Vermorken JB et al: Pharmacokinetics of free and total platinum species after short-term infusion of cisplatin. Cancer Treat Rep 68: 505$513,1984$.

14) Cole WC et al: Preparation and metabolism of a cisplatin/serum protein complex. Chem -Biol Interactions 30: 223-235, 1980.

15) Gonias SL et al: Complexes of serum albumin and cis-dichlorodiammineplatinum (II). J Biol Chem 258: 5764-5769, 1983.

16) Bergerat JP et al: In vitro cytokinetic response of human colon cancer cells to cis-dichlorodiam. mineplatinum (II). Cancer Res 39: 4356-4363, 1979. 
17）高橋克俊 他: Cis-dichlorodiammineplatinum(II).

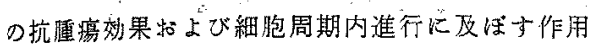
瘦と化学療法 9：624-631，1982.

18) Barranco SC et al: Bleomycin as a possible synchronizing agent for human tumor cells in vivo. Cancer Res 33: 882-887, 1973.

19）島田真路他：悪性黑色腫刀 Phase-synchronization

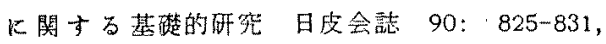
1980.

20)高本滋他: 杭癌性抗生物質の細胞回轱に和上ぼす 影䪪 一 Flow microflorometry 分析飞よる一。癌 々化学療法 6: 59-69, 1979.

21) Drewinko B et al: The response of synchronized human lymphoma cells to bleomycin and 1, 3-bis (2-chloroethyl)-1-nitrosourea. Cancer Res 33: 2732-2736, 1983.

22) Barranco SC et al: The effects of bleomycin on survival and cell progression in chinese hamster cells in vitro. Cancer Res 31: 1218-1223, 1971.

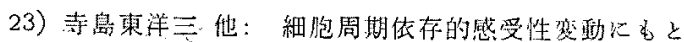

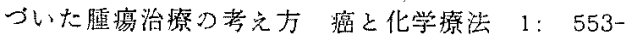
$541,1974$.

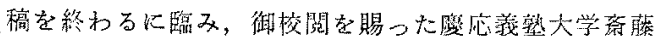
成司教授に深甚なる謝意を捧げます。また，終始暖かい

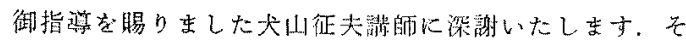

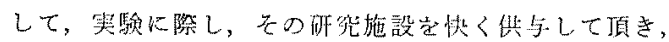

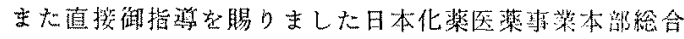

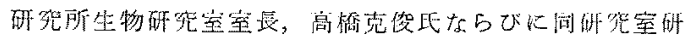
然員，四川清広氏に整心上り感謝いたします。

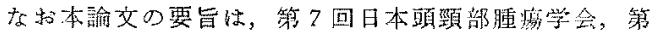
21 回日本癌治療学会，並び汇第22回日本癌治療学全汇招

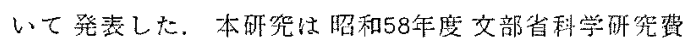
（No. 5877116）の援助による电のでする。

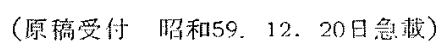

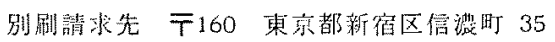

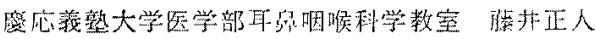

